\title{
The Settlement of Decolonization and Post-Colonial Economic Development
}

\author{
Indonesia, Malaysia, and Singapore Compared*
}

\author{
Nicholas J. White
}

Liverpool John Moores University, School of Humanities \& Social Science

n.j.white@ljmu.ac.uk

\begin{abstract}
Despite impressive growth in the early twenty-first century, Indonesia's economic performance in the post-colonial era lagged behind that of its neighbours in Malaysia and Singapore. The different development paths chosen, particularly in the treatment of foreign (and, especially, ex-colonial) investment, were central to this-Indonesia's rejection of Western capital in the 1950s and 1960s, and continued suspicion of foreign economic influence in the 1970s, contrasted with the more open approach of Malaysia and Singapore. How the post-colonial foreign presence was dealt with was largely conditioned by how decolonization was settled - the restrictive agreements reached between Indonesia and the Netherlands, and ongoing Dutch occupation of Irian Jaya, were sources of widespread resentment, and differed significantly from the more liberal approach of the British towards Malaysian and Singaporean independence. The short-term settlement of decolonization was therefore of greater significance than the longer-term nature of colonial rule in determining post-colonial economic patterns.
\end{abstract}

\section{Keywords}

Indonesia - Malaysia - Singapore - decolonization - post-colonial - economic development - foreign investment - localization

* Versions of this article were presented at the University of Leiden, October 2011, the School of Oriental and African Studies, February 2012, and Universiti Malaya, July 2012. I am indebted to Dr Ewout Frankema for his commentary in Leiden and the comments of two anonymous reviewers for this journal. Any errors are the author's.

(C) NICOLAS J. WHITE, 2017 | DOI: 10.1163/22134379-17302003

This is an open access article distributed under the terms of the prevailing CC-BY-NC license at the time of publication. 


\section{Introduction: Short-Term and Long-Term Colonial Legacies}

Compared to its neighbours in Malaysia and Singapore, Indonesia took a distinct development path in the post-colonial era. Indonesia nationalized Dutch assets between 1957 and 1959, and subsequently placed the remaining Western enterprises under government supervision between 1963 and 1965, constituting 'at the time the pinnacle of economic nationalism in modern Asian history' (Thee 2015:208). Malaysia and Singapore, however, continued with liberal policies towards expatriate enterprise. This article argues that heterogeneous patterns of decolonization influenced these different outcomes. The financial and economic 'settlements' for Indonesia in 1949 and for Malaya/Malaysia in 1957 and 1963 (as well as the terms of the final rundown of military bases in Singapore and Malaysia after 1968) explain much about subsequent economic developments. Firm guarantees for Dutch businesses in Indonesia, plus the transfer of debt obligations to the Republic, are contrasted with the looser arrangements for Malaysia and Singapore (and the ongoing supply of development and military aid by the UK).

The former Dutch and British territories in maritime Southeast Asia experienced similar post-colonial dependence upon export sectors dominated by ex-colonial enterprises. At least $70 \%$ of foreign direct investment (FDI) in earlyindependent Indonesia was Dutch (Lindblad 2008:22). In 1972, two-thirds of foreign capital in Malaysia was reckoned to be British (White 2004:6). The independent countries remained within ex-imperial monetary structuresthe Netherlands Monetary Area for Indonesia (to 1957); the sterling area for Malaya/Malaysia and Singapore (to 1972). The confluences notwithstanding, the contrasting, short-term nature of British and Dutch decolonization influenced how successor regimes addressed the alien economic presence. Moreover, the variegated responses to ex-colonial business are central to explaining the differing economic performances of the countries.

This comparative analysis contributes to debates about the efficacy of colonial rule. Lange's study of the long-term development legacies of British colonialism argues that directly ruled ex-British dependencies have fared betterin terms of contemporary Human Development Indices (HDI) - than their indirectly ruled counterparts (the UN's HDIs are based upon an amalgam of health, knowledge, and standard of living measures) (Lange 2009). Lange's earlier collaboration with Mahoney and Vom Hau 'revealed' the deleterious effects of Spanish mercantilist colonialism versus the liberal British model, but also differentiated between direct and indirect varieties of the latter: 'more extensive British colonialism introduced a rule of law, effective administration, and competitive markets, promoting development in the postcolonial period' 
while limited forms of British colonialism distorted existing institutions in ways that greatly hindered future development' (Lange, Mahoney and Vom Hau 2006:1414).

This argument is problematic, however, if Indonesia is compared with Malaysia and Singapore. As Lange, Mahoney, and Vom Hau themselves recognize, the patchwork quilt of ex-colonial administration in today's Malaysia makes it awkward to classify it as either directly or indirectly ruled. There were 'very powerful legal-administrative institutions' in the Straits Settlements (including Singapore) and the Federated Malay States, but 'much weaker' equivalents in the Unfederated Malay States and northern Borneo (2006:1430, 1433 n. 10, 1444). Moreover, Hutchinson (2015) argues that Johor, one of the most autonomous of the sultanates, achieved high levels of economic development, while contributing a disproportionately large number of administrators to Malaysia's post-colonial 'strong' state.

Additionally, the Dutch 'Ethical Policy', launched in 1901, produced a more interventionist form of rule in the Netherlands Indies compared to that in the Malay states (both federated and unfederated), where a minimalist, colonial, administrative tradition persisted until the Second World War. ${ }^{1}$ Economic intervention by the Dutch state in the archipelago was of a higher order than in 'laissez-faire' Malaya, reaching its zenith during the 1930s with food supply regulations, commodity marketing boards, and import-substitution industrialization (ISI). ${ }^{2}$ The Netherlands Indies' structures transmogrified into 'a monster [...] of an all-powerful, all-directing economic bureaucracy' in post-colonial Indonesia (Dick 2002:162). For Malaysia, a dirigiste colonial regime, largely in the context of counter-insurgency, only emerged from the late 1940s (White 2006:80-6; Hutchinson 2015:126, 150).

Yet, despite having a longer legacy of direct rule, post-colonial economic performance in Indonesia lagged behind that of Malaysia and Singapore. Between 1960 and 1970 - the UN's 'development decade' - GDP per capita (measured in 1985 us dollars) rose in Indonesia by a meagre $8.65 \%$; in Singapore, by a remarkable 81.5\%; and in Malaysia, by a more modest 40.7\% (Booth 2007:169). Indonesia can be regarded as 'part of the Asian economic miracle', experiencing sustained growth from the late 1960s, but it remains 'a poor country compared with some of its neighbours' (Henley 2012: s26, s27-31; Henley, Tirtosudarmo and Fuady 2012: $\$ 5^{2-3}$ ). According to the 2011 HDI, Singapore had

1 Ricklefs 1993:151-62; Moore 2015:233-4; Gullick 1992; Smith 1995:11-41.

2 Loh W.L. 2002; Van Zanden and Marks 2012:138-9; Frankema 2015:268-9; Dick 2002:161-2, 180; Knight 2015:170; Lindblad 2008:25-6. 
'very high human development', with a world ranking of 26; Malaysia achieved 'high human development' and took the 61st spot, while Indonesia managed 'medium human development' and was 124th in the global table. ${ }^{3}$ Indonesia shed its 'sick man of Southeast Asia' image in the 2010s. Britain's prime minister, David Cameron, arrived in Jakarta in April 2012, predicting that 'Indonesia [would] be a top ten economy'. ${ }^{4}$ Nevertheless, in 2015, Indonesia languished in 11oth place in the global HDI table, with Singapore leaping to 11th, and Malaysia dropping (slightly) to 62nd. ${ }^{5}$

By utilizing British late-colonial and post-colonial archives, as well as synthesizing the existing literature on decolonization in maritime Southeast Asia, this article argues that it was not so much the nineteenth- and twentiethcentury trajectory of colonialism that influenced post-colonial developments, but rather the nature of the shorter-term decolonization transition after the Second World War. Even within the small sample of Indonesia, Malaysia, and Singapore, the various approaches to FDI, and the diverse performance of the national economies which eventuated, owe much to the different ways in which independence was settled between the European imperial governments and the Southeast Asian nationalist elites.

\section{The Settlements Compared}

The terms of Indonesia's independence were settled at the Round Table Conference (RTC) in The Hague in the autumn of 1949. The price of political sovereignty for Indonesia was high: 'Few, if any of the newly independent nations were left with a more crushing external financial burden and such severe limitations in economic policy-making' (Thee 2010:38). In the Financieele en Economische Overeenkomst (Financial and Economic Agreement; hereafter FINEC), Indonesia inherited the Netherlands Indies' pre-Pacific War foreign debt. This amounted to $f 3.5$ billion, repayable to the Dutch government, and an additional $f 1.5$ billion of external debt. A us $\$ 100$ m loan, repayable with interest, from the Us Export-Import bank was poor compensation (Thee 2010:36; Round Table Conference 1950:34-5).

In contrast, in the financial settlement for independent Malaya in 1957, Britain transferred unspent funds allocated for the expansion of the Feder-

\footnotetext{
3 http://hdr.undp.org/en/statistics/, Table 1, accessed 26-1-2012.

4 'David Cameron: Indonesia is a big opportunity for Britain', Daily Telegraph, 11-4-2012.

5 http://hdr.undp.org/en/composite/HDI, Table 1, accessed 17-10-2016.
} 
ation's armed forces and for development and welfare. Moreover, continued assistance was provided post-independence towards the cost of the Emergency - the undeclared war against the Malayan Communist Party (MCP) guerrillas (Stockwell 1995a:lxxix). Up until 1961, at the lowest estimate, this represented a commitment from Her Majesty's Government of $£ 27$ million. ${ }^{6}$ During the creation of Malaysia in 1963 , meanwhile, Britain agreed to provide a $£_{7.5}$ million grant towards the economic development of Sarawak and Sabah (as well as an interest-free loan of $£_{5}$ million), and some $£ 16.5$ million to 1965 for the raising of battalions in Borneo. ${ }^{7}$ In addition, the Anglo-Malayan Defence Agreement of 1957, extended to Malaysia in 1963, allowed for the continued presence of British troops and bases on Malayan/Malaysian soil. Kuala Lumpur and Singapore were relieved of much of the cost of their external defence. ${ }^{8}$ This would come to the fore during Indonesia's confrontation with Malaysia between 1963 and 1966, when over 6o, ooo British service personnel, 200 aircraft, and 80 naval vessels were deployed in Southeast Asia (Jones 2002). Moreover, in the subsequent rundown of UK military forces, London provided compensatory aid $— £ 50$ million for Singapore; $£_{25}$ million for Malaysia (Loh K.S. 2011; White 2004:114).

A greater source of post-colonial tension between the Netherlands and Indonesia, however, were those clauses in FINEC designed to preserve Dutch business operations. Indonesia did receive the concessions of, 'inclusion within the earliest possible period of eligible Indonesians into the direction (and management) and staffs' of overseas-controlled firms, 'and cooperation in establishing training courses with the objective that after a reasonable period, the predominant part of the leading staff personnel of the enterprises will consist of Indonesian nationals' (Round Table Conference 1950:28). But no targets or deadlines were set for the Indonesianization of management. Moreover, rights, concessions, and licences granted under the Netherlands Indies administration would be upheld, and could be renewed and extended, or new rights granted, guaranteeing 'a continuity' and so 'making possible the investments required for normal long term business operations'. Moreover, '[e]xpropriation, nationalization, liquidation, compulsory cession or transfer of properties

6 Telegram from Foreign Office, 4-2-1957, CO 1030/494, The National Archives of the United Kingdom (hereafter TNA), in Stockwell 1995c:359-6o.

7 Memorandum by Sandys, 11-6-1963, 134/2371, TNA, CAB 134/2371; Cabinet Oversea Policy Committee minutes, 17-6-1963 in Stockwell 2004b:503, 509-10.

8 Profumo to Macmillan, Appendix A, 12-8-1957, CO 1030/833, TNA in Stockwell 1995c:408-12; Ormsby-Gore to Home, 15-2-1963, FO 371/1699o8, in Stockwell 2004b:445. 
or rights' were only permitted if they could be proven in the public interest. In the absence of agreement, compensation for such expropriations would be determined by a judicial review based upon the real value of the assets involved. Indonesian capital participation in foreign companies was encouraged, but only 'subject to this being justified from a business point of view'. Taxation, meanwhile, was to be set at a level to permit 'normal replacements, depreciations and reserves and permitting a reasonable profit for the capital invested'. Dutch nationals and corporations would enjoy no less favourable treatment in Indonesia than that accorded to any third country, and indeed Indonesia was required to respect their 'special interests'. Additionally, consultation between The Hague and Jakarta was expected on exchange rates and controls, and financial and monetary measures generally. Indonesia, meanwhile, could only place restrictions on transfers to the Netherlands of profits, interest, and pension payments in view of the Republic's foreign exchange position and in consultation with The Hague. There was also expected to be close cooperation between Indonesia and the Netherlands on foreign trade policy, and consideration of a 'system of mutual preferential treatment' (Round Table Conference 1950:23-9, 31-2; Thee 2010:36-7). The RTC 'more or less guaranteed unrestricted operations by Dutch business enterprises in Indonesia' (Van Zanden and Marks 2012:137). Consequently, there was a high degree of Indonesian resentment towards ex-colonial firms. A manager at the Hong Kong and Shanghai Banking Corporation (HSBC) recalled his time in Indonesia in 1956: 'The Dutch banks had a complete hold on practically all the major business in the country, which annoyed the Indonesians. ${ }^{\prime 9}$

As per post-colonial debt and aid arrangements, the UK government took a different approach to post-colonial investment guarantees in Malaya. Far from a 'bargain' being struck by British interests and the 'Malayan elite' in the decolonization process to forestall nationalization (Jomo and Wee 2014:623), the absence of any strings being attached at independence allowed the Malayan/Malaysian state more room for manoeuvre and created much less resentment towards so-called 'neo-colonialism' than was the case in the stormy course of post-colonial Dutch-Indonesian relations.

Policymakers in London certainly came under pressure from metropolitan business interests to institute guarantees similar to those afforded to their Dutch colleagues in the archipelago. Malaya's constitutional conference of January-February 1956 fixed the date of full independence for August 1957. Appended to the report of the conference was an extract from an address by

9 S.F.T.B. Lever interview, 20-8-1980, 1641/036, HSBC Group Archive, London. 
the high commissioner of Malaya to the Federal Legislative Council in November 1955 (Cmnd. 9714: Appendix F). This followed the election of the Alliance government to share power with the remaining British colonials. The Malayan Commercial Association of Great Britain (MCAGB) objected to the high commissioner's suggestions. '[F]air and considerate' treatment would be given to overseas capital, while the unobstructed remission of dividends and capital would continue. Yet, in return, the Malayan government expected expatriate enterprises to indigenize technical and managerial posts, reinvest a 'reasonable proportion' of profits and, 'whenever possible', transfer the seat of direction to Malaya. What worried the MCAGB was that the Federation government might force transfers of domicile to Kuala Lumpur, introduce employment quotas, and restrict the entry of expatriates. Disputes might erupt between U K investors and the Malayan authorities regarding the qualifications required by local staff as well as what the MCAGB, in thinly veiled racist colonial jargon, called the 'personal attributes of steadiness and calmness of judgment'. ${ }^{10}$

The businessmen argued that the absence of an economic agreement would make it 'all the easier for a Government to disregard the interests of overseas enterprises'. In July 1956, Malaya's finance minister, H.S. Lee, was scheduled to visit the UK to negotiate the financial settlement for independence. The MCAG B hoped that a quid pro quo (protecting British firms in post-colonial Malaya) could be extracted in return for continued UK aid post-1957. ${ }^{11}$

Cabinet ministers in London considered securing a binding undertaking from Malaya to safeguard British investments before the talks in early 1956; however, Whitehall mandarins advised against it. It was reasoned that a Neth-

10 Rubber Growers' Association Council minutes, 4-6-1956, 24863/66, report of General Purposes Committee, London Metropolitan Archive.

11 Rubber Growers' Association Council minutes, 4-6-1956, 24863/66, report of General Purposes Committee, London Metropolitan Archive. Although British business leaders increasingly sang the praises of the Alliance government in public, behind closed doors there remained concern as independence approached that the moderate Alliance could easily be overthrown given the ongoing presence of militant leftism and/or Islamic revivalism (White 1996:147-8, 168). Meanwhile, there were worries that the Alliance itself harboured anti-capitalist tendencies. Immediately after the election results, in the summer of 1955, RGA leaders approached the Colonial Office alarmed at 'reports from Malayan sources that Alliance candidates in campaign pledged their Party to confiscation of European estates and their distribution to smallholders'. A feared bogeyman was Abdul Aziz bin Ishak, the new minister for agriculture and leader of the left wing of the United Malays National Organization (UMNO). Telegram from Colonial Office to Governor Singapore (for MacKintosh from Poynton), 17-8-1955, FCO 141/7479, TNA. 
erlands-Indonesia, FINEC-style agreement might be later regarded as a limitation on sovereignty; it might appear to question the Alliance government's integrity. In addition, it was said that the well-being of British firms in Malaya hinged 'upon the cultivation of good will', not a legal document'. Moreover, in post-independent India, Pakistan, and Burma, British companies had encountered difficulties such as nationalization and punitive taxation, which could not have been avoided by any such document. Crucially, 'the sort of assurances we could expect to secure in any formal agreement are not as valuable to us as the recognition of mutual interest and the establishment of understanding and cordial relations'. Instead, Conservative ministers were content with the insertion of a paragraph in the final report which recognized assuring statements in Alliance election manifestos, and a vague commitment to 'fair and considerate treatment' to overseas capital. The report of the constitutional mission of 1957, moreover, rejected a post-colonial guarantee-it was not 'right or practicable to attempt to limit developments of public opinion on political, social and economic policy'.12

With regards to property rights, Article 13 of the Malayan/Malaysian constitution stated that 'no person shall be deprived of property save in accordance with law' and 'no law shall provide for compulsory acquisition or use of property without adequate compensation'. Yet, this was 'adequate' not 'fair' compensation and there was no stipulation à la Indonesia that reimbursement should be based on 'real' values (Trinidade and Lee 1986:193-5; Suffian 1976:220-1; Groves 1978:34-5). Article 26 of the draft constitution of the Republik Indonesia Serikat (Republic of the United States of Indonesia) stated that '[e]xpropriation of any property or right for the general benefit cannot take place except with indemnification and in accordance with regulations as established by law' (Round Table Conference 1950: Appendix 9). This was equally as vague, then, as the situation in Malaya/Malaysia. However the latter was not required to also provide FINEC-style investment guarantees. Moreover, Singapore deleted Article 13 from its constitution after leaving Malaysia in 1965. Nevertheless, the Peoples' Action Party (PAP) government pursued an export-orientated manufacturing strategy. Singaporean post-colonial capitalism was highly planned, involving a myriad of government-linked corporations. But the PAP's 'statecoordinated, liberal market economy' nurtured capital and technology inputs from multinational enterprises, and did not nationalize foreign-owned firms (Ritchie 2009:437; Huff 1994:299-36o). Paradoxically, in 1971, it was the inde-

12 White 1996:142, 172-3; Draft cabinet memorandum by Lennox-Boyd, c. Feb 1956, co 1030/ 72, TNA, in Stockwell 1995c:257-8. 
pendent Singaporean government, not the departing imperial regime, which instituted an investment guarantee for British firms. ${ }^{13}$

Admittedly, both Malaysia and Singapore suffered financial and monetary constraints through their continued membership of the sterling area and the linking of their currencies to the UK pound until the early 1970 (and this, as we will see, was a major problem for Anglophone Southeast Asia, as the British economy floundered from the mid 196os). But the sterling-area system was liberalized by Malaya's independence in 1957. Malaya won self-determination in dollar expenditure after the January-February 1956 powwow in London. Import restrictions on dollar goods were lifted steadily throughout the sterling area, with the eventual goal of full convertibility. After 1959, Singapore merchant houses were able to do substantial business directly with North America, and from 1960, Malaya began accumulating its own, independent dollar reserve. Moreover, the ongoing financial link to Britain did not prevent the Federation from concluding most-favoured-nation trade deals outside the Commonwealth bloc —notably with Japan in 196o. By 1965-1966, Japan was Malaysia's main trading partner, as well as a major supplier of capital and knowhow for the country's industrialization process (Sutton 2015:150-1, 170-1; White 2010:156, 161-70).

Why did the Netherlands and Britain take these different approaches to the decolonization settlements? One reason why the British did not insist on investment guarantees was that the Malaysian region was declining in economic significance for the UK (as indicated by financial liberalization). Malaya's dollar earnings from massive sales of rubber and tin to the United States were crucial to British reconstruction after the Second World War, and (combined with Singapore's role as the outer ring of defence for Australasia) explain the UK's determination to crush the MCP after 1948 (Sutton 2015; Stockwell 1986). However, by the mid 1950s, Britain's dollar crisis was less pronounced, and new trade and investment strategies were drawing UK businesses away from the Empire/Commonwealth towards Europe, Japan, and the United States. Meanwhile, the development of a synthetic rubber industry in the UK made Britain less reliant on Malayan raw-material supplies (White 2010:155, 158). The independence of Indonesia, however, came at a time when the Dutch viewed the archipelago's raw-material supplies and hard-currency earnings as crucial to metropolitan reconstruction. Such economic imperatives had underpinned the 'police actions' of 1947-1948 against the Republic. But, as Van der Eng $(1988: 336-7,347-52)$ argues, the acceptance of independence by the Dutch 
cabinet in The Hague was also conditioned by a confidence that the Dutch economic stake in Indonesia could be secured by meeting Republican constitutional demands, while also preserving us Marshall Aid disbursements to the Netherlands.

In its exits from Malaysia and Singapore, Britain benefited from an inheritance of decolonization: it was able to learn from the mistakes of the American Revolution in the late eighteenth century and from the setting up of selfgovernment for the settler colonies in the nineteenth century (Boyce 1999:2143). The examples of Canada, Australia, New Zealand, South Africa, and even the Irish Free State/Eire (after 1922) demonstrated that a loosening of formal ties need not mean the end of metropolitan economic influence (Hopkins 2008; Jeffery 2011:328). The term first used by British officials for a self-governing Malaysia was the 'British dominion of Southeast Asia', suggesting that the UK was expecting Malaysia to follow the 'White' Commonwealth model of influence through devolution (Stockwell 2004a:xxvii). This experience was lacking in the Dutch Empire. À Campo (1998:37) argues that the smoother economic transition in India after independence, compared to Indonesia, reflected Britain's more 'flexible and pragmatic' approach to 'empire-building and decolonization'.

But this stress on British 'exceptionalism' has been questioned in comparative analyses of decolonization (Thomas, Moore and Butler 2015:332-45). The British were as determined to reconstruct their Southeast Asian empire postwar as the Dutch. The Malayan Union (and later Federation), like the Dutch federal scheme for Indonesia, was designed to prolong the colonial presence, as were the overarching structures of the reformed imperialism-the Dutch and British multi-racial commonwealths. When local political groups refused to accept these 'partnerships', the British were equally prepared to use extreme violence and engage in human-rights abuses to secure what were considered vital economic interests for metropolitan revival. The offensive against the MCP should not be regarded as distinct from the Dutch 'police actions' in Indonesia (White 2011).

Short-term exigencies therefore remain more important than long-term inheritances. The timing of devolution proved crucial in explaining differing British and Dutch attitudes towards their Southeast Asian territories. Britain's declining economic interest in Malaya/Malaysia by the second half of the 1950s made independence, without financial and investment strings attached, possible to contemplate. For the Netherlands in the late 1940s, Indonesia was perceived as crucial to economic survival. Indeed, as Holland argued, Dutch acquiescence to Indonesian and us pressure in surrendering Irian Jaya by the early 1960 os was made that much easier by the 'new assets and opportunities' 
of the post-colonial era: 'the rich revenue from North Sea gas strikes and the prosperity generated by the drive towards west European integration' (Holland 1985:93).

It should still be remembered, however, that the British decolonization strategy for Malaya/Malaysia and Singapore-just like the Dutch strategy for Indonesia - was predicated on the belief that a large slice of economic, military, and cultural influence could be preserved in the post-colonial state (Stockwell 1986; Subritzky 2000:211, 212-3). Where the Dutch differed was that they were much more explicit about their influence as a result of both FINEC and their clinging on to West New Guinea.

\section{Consequences for Foreign Investment}

The restrictions placed on the freedom of manoeuvre in post-colonial Indonesia made it much easier for malcontents to critique the ongoing plural economy. The drawn-out decolonization processes in Malaysia and Singapore resulted in the isolation of the extreme left. The Emergency on the mainland after 1948 marginalized the economic radicals as the Malay left was lumped together with the overseas, Chinese-dominated MCP. The leftist and pro-Indonesian Partai Kebangsaan Melayu Malaya (РКMM, Malay Nationalist Party) was not banned after the declaration of the Emergency. Nevertheless, Ikatan Pemuda Tanah Ayer (PETA, Youth League of the Fatherland), an offshoot of its militant youth wing, was proscribed by the colonial authorities, and prominent PKMM leaders were detained or took to the jungle alongside the MCP guerrillas (White 1996:138-9; Harper 1999:124-6). ${ }^{14}$ The traditionalist U MNO emerged instead as the champion of the kampung, and after 1953 its aristocratic leadership formally allied with communal parties dominated by ethnic Chinese and Indian business leaders (Amoroso 2014:211-28). Despite British fears that the election of the Alliance in 1955 might herald an Indonesian-style rapprochement with the communists, the Baling Talks in December resulted in Chin Peng, leader of the MCP, returning to the jungle rather than becoming a member of parliament (Stockwell 1995a:lxxvi). In Singapore, Operation Coldstore in February 1963 incarcerated the radical left-wing challenge to the moderate socialist, Lee Kuan Yew (Jones 2002:118). The 'patriotic' factor during the Konfrontasi (Confrontation) with Indonesia bolstered the position of the Alliance

14 Supplement to Malayan Security Service Political Intelligence Journal, 15-8-1948, CO 537/ 3753, TNA, reproduced in Stockwell 1995b:53-65. 
government in the 1964 elections. A new state of emergency also led to the arrest of pro-Indonesian radicals (Means 1976:338, 340-1).

Despite the abortive Madiun uprising of 1948, the Partai Komunis Indonesia (PKI, Indonesian Communist Party) and the leftist wing of the Partai Nasional Indonesia (PNI, Indonesian National Party) were not eliminated in either the war with the Dutch or the internecine struggles of the Revolution. Rather, these radical groups, which had called for sequestrations of foreign-owned assets during the independence struggle, were given succour by the Dutch 'neocolonial' presence (Stoler 1985:104). In Indonesia's first national parliamentary elections in September 1955, the PKI won $16 \%$ of the vote (concentrated in East and Central Java). Following the de-Dutchification of trade and investment, and the institution of Guided Democracy, the PKI was indirectly incorporated into the regime as President Sukarno adopted its key tenets in his NASAKOM philosophy, and attempted to exploit the communists as a counterweight to the military (Cribb 2000:163, 166).

In 1950, the Barisan Tani Indonesia (вті, Indonesian Peasant Front), particularly active in the plantations and affiliated to the PKI, declared that, 'Indonesia is a tool serving the restoration of the old order in a new form. Foreign capital still controls Indonesia's mines, plantations, factories, land-, sea- and air-transport facilities.' The BTI was committed to the nationalization of foreign enterprises, and the redistribution of plantations to the landless (Pelzer 1982:56-7, 58-9). Unionized estate workers supported the Republic in the violent struggles of the late 1940s. They made spectacular wage gains in the early 195 os, but became increasingly alienated from the Jakarta government by a failure to challenge 'the basic relations of production on which exploitation was based' (Stoler 1985:111-23, 126, 127). ${ }^{15}$ Indeed, Sjafruddin Prawiranegara, minister of finance in 1950-1951 and first governor of the Bank Indonesia, blamed strikes, thefts, lootings, and the burning of estate crops for the declining productivity of foreign-exchange-earning plantations (Thee 2010:42). However, the pragmatic moderates, who were prepared to tolerate foreign investment in the medium-term, became isolated in central government. In the late 195os, Sjafruddin, as well as Sumitro Djojohadikusumo (a minister of trade and industry and twice minister of finance in the first half of the 1950s), joined a rebellion in West Sumatra against Sukarno (Thee 2010:40).

15 Port workers had a similar experience, achieving wage increases 'out of proportion' in the 1950s, but also being at the forefront of labour confrontations with foreign-owned shipping companies. À Campo 1998:29, 34; White 2012:1288-9, 1302-3; 'Djakarta. Jan-Mar 1965', Holt to Gleichman, 15-3-1965, OA/1869/2, Merseyside Maritime Museum, Liverpool, Ocean Archives (hereafter OA). 
Frustrations with the ex-imperial economic presence were compounded by the entrenchment of the Dutch in Irian Jaya after 1949. Pragmatic business interests forewarned of the dangers-Dutch relations with Indonesia were likely to be irreparably damaged by continued possession of the Papuan territory. For Anglo-Dutch Unilever, a power-sharing agreement in Irian Jaya for a further 25 years between the Netherlands and Indonesia would relieve tensions (Penders 2002:218, 347; Lindblad 2008:161; White 2012:1307-8). But the government in The Hague ignored the soap and food manufacturer's advice. When talks between Indonesia and the Netherlands collapsed in February 1956, Jakarta unilaterally withdrew from the Netherlands-Indonesian Union and repudiated FINEC (Pelzer 1982:127). European enterprises noted a tightening of the screw. The Liverpool-based Ocean Steam Ship Company (OSSCo) (also known as the Blue Funnel Line) was the largest British shipping interest in Southeast Asia, with a Dutch subsidiary, the Nederlandsche Stoomvaart Maatschappij 'Oceaan' (NSMO). NSMO's wharves in Jakarta, Makassar, and Surabaya now had to be operated by Indonesian companies. ${ }^{16}$ At the end of November 1957, Indonesia's request to the UN General Assembly to have the issue of the surrender of West New Guinea put on the agenda of the Security Council failed to achieve the two-thirds majority required. From 3 December 1957, Dutch firms were 'held responsible for everything that was going wrong', taken over by trade unions, and quickly placed under military supervision (Lindblad 2008:182-5; Lindblad 2010:104).

The British, by contrast, relinquished North Borneo/Sabah, Sarawak, and Singapore in the creation of Malaysia in 1963. The departure of Singapore from the enlarged Federation in August 1965 was not a British neo-colonial plot. It was a locally agreed deal, which the British government only became aware of when the split was a fait accompli. ${ }^{17}$ Singapore's exit looked disastrous to British economic interests, because the micro-state might fall under Indonesian or Communist Chinese influence, while the interconnections of mainland and island would be shattered (White 2004:42-6). Similarly, British interests did not engineer Brunei's refusal to join Malaysia back in 1963. Both the British government and Royal Dutch Shell regarded a British-protected Brunei as an international embarrassment, and highly vulnerable to Indonesian irredentism (Stockwell 2004a:lxxxiii-iv; White 2004:46-8). The UK and Malaysia continued to consult on Brunei's progress towards independence. UK diplomats appreci-

\footnotetext{
16 Blue Funnel and Glen Lines Staff Bulletin, July 1956:171-2, OA/696/2.

17 Prime Minister Harold Wilson cut short his holiday on the Scilly Isles to review the 'potentially dangerous problem' (Wilson 1971:130-1).
} 
ated in 1977 the danger to Britain's stake in Malaysia 'if the negotiations with Brunei turned sour or [went] too slowly'.18

Britain's acquiescence in the creation of Malaysia (as well as its non-interference in Singapore's departure or Brunei's rejection) reinforced the authority of moderate policymakers in Anglophone Southeast Asia. In the Indonesian case, however, Thee (2003:20) believed that 'the major reason for the decline in political influence of [the pragmatic economic policymakers] was the refusal of the Dutch to discuss the future status of West Irian and the continuing economic domination of Dutch business'. In justifying the nationalization of Dutch assets in 1959, Minister of Agriculture Sadjarwo told the press that 'the Indonesian-Dutch dispute over West Irian [...] precipitated the decolonization process of Indonesia's economy. [...] [T] he country's economic structure had remained colonialist in spite of the political freedom. The Dutch still retained their economic privileges and the Indonesian economy was still under their control' (Pelzer:170).

Nationalization rapidly increased the presence of state-owned enterprises in the economy, with 'a much more "socialist" approach to economic problems' since 'there was now much less concern about discouraging foreign investment'. Under Sukarno's Guided Economy, the Foreign Investment Law of 1958 (Undang-Undang tentang Penanaman Modal Asing, UU 78/1958), which encouraged joint ventures but continued to permit transfers of profits and dividends, was overridden (Thee 1996:321, 328). In the opposite direction, Malaya's prime minster, Tunku Abdul Rahman, called for an international charter to attract foreign capital throughout Asia (White 2004:60). Indeed, Malaysian policymakers, like their Singaporean counterparts, were careful not to disturb existing trade and investment channels through new initiatives. Hence in 1968, British bankers and traders were reassured by officials from Malaysia's central bank (Bank Negara) that new exchange controls would be introduced in such a way as to avoid disruption of 'the special position of London as a financial and trading centre for Malaysian produce' (whereas, between 1958 and 1965, Indonesia's state-owned enterprises bypassed the commodity markets in Amsterdam and Rotterdam in favour of Antwerp, Bremen, and Hamburg, and also tried to trade increasingly with the communist bloc). ${ }^{19}$

18 Cortazzi to Simons, $23-3-1977,15 / 2237$, FCO 15/2237, TNA.

19 Note by McCulloch, 12-2-1968, in Kuala Lumpur to London, 16-2-1968, 37612/8, London Metropolitan Archive, Harrisons \& Crosfield Ltd (hereafter H\&C); Memorandum of meeting with Amien Tjokrosuseno, PPN Baru in Hobhouse to Holt, 25-10-1958, OA/2385; Lindblad 2008:188; White 2012:1300. 
This patience was all the more remarkable given that Anglo-Malaysian (and Anglo-Singaporean) relations encountered a rocky patch between 1967 and 1972, from the devaluation to the float of sterling. Malaysia's minister of finance, Tan Siew Sin, was repeatedly assured by the chancellor of the exchequer, James Callaghan, that there was no question of devaluation. Malaysia, the secondlargest government holder of sterling assets after Australia, took a huge hit therefore in November 1967 , losing M $\$ 250$ million (US $\$ 81.5$ million). Singapore was less exposed, having clandestinely diversified its reserves before devaluation to about 50\% sterling (whereas Malaysia still held 80\%). However, in January 1968, when Harold Wilson announced an accelerated military withdrawal from 'East of Suez', both countries suffered a second trauma induced by the UK's financial crisis. The sterling float of June 1972 made a triple whammy, costing Singapore $\$$ \$ 45 million (US\$16 million) and Malaysia M \$59 million (US\$21 million) (Schenk 2008:203, 219; White 2004:112). Tan denounced the float as a 'de facto devaluation' and a unilateral dismantling of the sterling area. ${ }^{20}$ Britain's imminent entry into the EEC also worried Singapore and Malaysia — not from a trade perspective, but because there would be less UK investment and lending to go round. ${ }^{21}$

Yet, in contrast to Indonesia in the 1950s, anger was vented in Malaysia and Singapore in the 1960s and 1970s at the ex-colonial power's incapacity to contribute to economic development rather than its alleged neo-colonialism. Britain was censured for doing too little rather than too much, and there was minimal retaliation against British interests. The Uk's refusal to provide additional military aid for Malaysia post-1966 led to the withdrawal of Commonwealth preferences on British imports, contributing to a significant downturn in British trade with Malaysia (White 2004:8-10, 207). Post-1972, Malaysia and Singapore adopted the us dollar as their intervention currency, and Malaysia abrogated its sterling-area agreement and diversified widely into other European currencies (to match Singapore). Yet, neither country instituted exchange controls against the ex-sterling area. ${ }^{22}$ Moreover, the Bank of England was confident that Malaysia would not nationalize British interests. Decision makers in Kuala Lumpur were 'far too interested in private direct inward investment in general.'. ${ }^{23}$ Rather, regret was expressed that Britain could hardly look after itself let alone act as the economic head of the Commonwealth. Tan Siew Sin

\footnotetext{
20 Negotiating brief: Malaysia, 5-7-1972, OV 44/245, BoE.

21 Stone to Haslam, 15-1-1971, OV 44/244, BoE.

22 Hopcroft to Chick, 11-8-1972; Peskett for Stone, 27-10-1972; Stone for Payton, 27-6-1972 and 11-7-1972, ov 44/245, BoE.

23 Stone for Fenton, 8-11-1972, OV 44/244, BoE.
} 
complained in April 1972 to a UK Treasury official about a British rate of inflation 'normally associated with a developing country', trade unions that were 'as powerful as the Government', and a dangerous predilection for 'stop-go economics.'. ${ }^{24}$ In June 1977, Malaysia's prime minister, Hussein Onn, lamented to David Owen, the Uk's foreign secretary, that Britain

was losing ground in Malaysia in the commercial field. There was profound goodwill for the British and respect for the quality of British products, but the British were just not aggressive enough, in respect not only of Japanese competition but the increasing involvement of the French and now the West Germans. ${ }^{25}$

After 1966, bar Dutch enterprises, the Soeharto regime in Indonesia did encourage the return of foreign investments sequestered during Konfrontasi on favourable terms (White 2012:1312). New waves of FDI from American, European, and East Asian MNEs were actively sought out. Yet, the Orde Baru (New Order) was not necessarily that new. Many of its administrators cut their teeth during the Sukarno years. Soeharto himself was a veteran of the guerrilla war against the Dutch, much of which had been directed at sabotage of Dutch and other foreign-owned enterprises (Van Zanden and Marks 2012:137; Henley, Tirtosudarmo and Fuady 2012: 567 ). By 1967, a former favourite of Sukarno's, Brigadier Ali Sadikin, was the governor of Jakarta. As minister of sea communications, he had railed in 1964 against the Europe-Indonesia shipping conference as a 'tool of imperialist domination'. ${ }^{26}$ Moreover, the reservation of government cargo to Indonesian-registered ships (dating from Sadikin's time in Sukarno's cabinet) continued until 1985 (White 2012:1314).

Equating foreign investment with colonialism was a difficult notion to shake off for the Orde Baru elite. Despite the counter-revolutionary nature of Soeharto's agricultural development, these pro-poor programmes 'reflected a history in which the ideal of social justice [...] played a powerful role' (Henley, Tirtosudarmo and Fuady 2012: 567 ). George Holt, the Indonesia specialist on the OSSCo board, visited Jakarta in 1967 and reported on a widespread distrust of communist-style institutions; however, " $[\mathrm{s}$ ] ocialism still remain[ed] the ideal'. Holt hoped that 'a good deal of the complicated socializing legislation

\footnotetext{
24 Meeting with Raymond Bell, 13-4-1972, OV 44/245, BoE.

25 Note by South East Asia Department, 21-6-1977, 15/2237, FCO 15/2237, TNA.

26 Notes by Holt, 20-4-1967 and 11-3-1969, OA/JLA/20/1; Confidential translation, 13-11-1964, $\mathrm{OA} / 1696 / 2$.
} 
of the previous regime will be swept away' ${ }^{27}$ Yet, five years later, Ocean directors were informed that '[i]nvestment in Indonesia remains complicated by Government regulations and bureaucratic procedures' (including widespread corruption - another hangover from the Sukarno era). ${ }^{28}$

Indeed, with economic stabilization boosted by oil revenues, a Sukarnoesque form of economic nationalism resurfaced in the 1970s. Local equity participation requirements were pushed to $51 \%$, the employment of foreign personnel was restricted, and tax incentives were also declined. The pragmatic 'Berkeley mafia' of economists only reasserted their authority in the 1980 (Hill 1998:30-1; Weinstein 1974:279-80, 281, 284-5; Henley, Tirtosudarmo and Fuady 2012: \$54-55). In 1967, Holt found the Soeharto regime appreciative of the fact that its survival depends upon [overseas] aid and credit [...], and that they will only get them if they can inspire confidence. ${ }^{29}$ But in 1976 Indonesia's risk-rating remained high. The leading British merchant bank, Barings, advised Ocean against tying up sizeable assets in a project to ship liquid natural gas from Indonesia to Japan. This was partly due to technological imponderables, but also because of the 'political risk' involved. ${ }^{30}$

In Malaysia, meanwhile, the New Economic Policy (NEP) was being introduced. It was designed to nurture a Malay—or bumiputera — managerial and entrepreneurial class, while also increasing the share of the corporate economy owned by non-Malay Malaysians. The consequence was 'a great increase in the formation of quasi-public bodies and government agencies that were charged with providing special assistance programmes for Malays or that acted as surrogate institutions for the transfer of capital shares and ownership to Malays' (Means 1991:25-6). During 1975, the encroachments of Malaysian parastatals and ethnic Chinese investors into the ownership of British plantation and mining groups, the insistence by Malaysian officials that British firms reserve at least $30 \%$ of their equity in Malaysia for bumiputera interests, and amendments to petroleum legislation led to a significant blip in foreign-investor confidence. ${ }^{31}$ Yet, there remained 'no sign of a governmental desire to deprive people of property, whether by nationalization or otherwise, without adequate compensation' (Sheridan 1977:17, cited in Trinidade and Lee 1986:193).

In September 1981, a dawn raid was launched on the London Stock Exchange on the premiere British plantation group, The Guthrie Corporation. Guthrie

27 Note by Holt, 20-4-1967, OA/JLA/20/1.

28 Board memorandum, 20-8-1973, Appendix 5-6, oA/862.

29 Note by Holt, 20-4-1967, OA/JLA/20/1.

30 Taylor to Alexander, 12-7-1976, OA/2412/5.

31 Material in TNA, FCO 15/2075-2076. 
was swiftly taken into Malaysian control. The raid resulted in tense relations between London and Kuala Lumpur, culminating in Prime Minister Mahathir's 'Buy British Last' campaign. This hit UK consultants and contractors hard. ${ }^{32}$ Nevertheless, Permodalan Nasional Berhad (PNB, the National Equity Corporation), the quasi-governmental Malaysian investment agency, was scrupulous in its observation of stock exchange rules during the takeover of Guthrie. This avoided charges of nationalization to fortify overseas business confidence. Moreover, amicable Anglo-Malaysian relations were restored relatively swiftly. If British firms complied with the requirements of the NEP, UK investment was still embraced. Should British interests be localized, expatriate managers were assured of continuity of employment (Shakila and White 2010:937-40, 941-4, 955-6). The chairman of PNB told the British high commissioner in July 1982 that 'whilst in many cases titular control for Malaysians was important for political reasons, day to day control of management was quite another.'33

The Malay chauvinists, who now dominated UMNO, believed in majority local control of resource-based industries. This did not mean that multinational enterprises were eschewed, though. In the Korean- and Taiwanese-style Free Trade Zones, FDI was sought out in export-orientated manufacturing. Much of this sector remained foreign-owned until the twenty-first century (Shakila and White 2010:955; Jomo and Wee 2014:16-7, 46). British investment in high-technology industries, especially where there was a potential regional export market and local raw materials were being exploited, was still encouraged. Mahathir's bark proved worse than his bite-at the height of his antiBritish campaign, in 1982, the prime minister welcomed a project for the manufacture of cement building-board. Though a joint venture between a UK firm and a bumiputera group, the former held $80 \%$ of the equity. The Malay holding would be increased to $40 \%$ by 1990 to comply with the NEP, but Mahathir 'very much hoped' this would be achieved by expansion rather than by divestment on the part of Shand Kydd, the British partner. A Foreign \& Commonwealth Office mandarin reminded his colleagues that U K firms could still establish new enterprises in Malaysia with a majority shareholding in their favour, 'something that is denied us in many other parts of the developing world'. ${ }^{34}$

Malaysianization was a gradual process. The indigenization of Dutch enterprises in the late 1950s was accompanied by a mass expulsion of $50-60,000$ Dutch personnel from Indonesia. There was no equivalent exodus in Malaysia.

32 White to Brown, 30-9-1982, 15/3268, FCO 15/3268, TNA.

33 Note by Bentley, 2-7-1982, 15/3268, FCO 15/3268, TNA.

34 Bentley to London, 18-8-1982, 15/3268, FCO 15/3268, TNA. 
From 1963 onwards, it was difficult for British enterprises to employ European managers. Nevertheless, the authorities remained flexible - a number of 'key posts' were retained by expatriates where those managers were deemed to be directly responsible to the boards of overseas companies. In 1968, a Plantation Industry Malaysianization Committee (PIMC) was established and an industry-wide standard for 'top-echelon' representation was agreed with the government. ${ }^{35}$ Claude Fenner, the special representative in Malaysia of the British-dominated Rubber Growers' Association (RGA), was chair of the PIMC, emphasizing Anglo-Malaysian continuities in the post-colonial period. Fenner had been the last British commissioner of police of the Federation of Malaysia, and the first inspector-general of police for Malaysia until 1966. His appointment to the RGA position was supported by senior Malaysian leaders. On Fenner's death in Malaysia in 1978, the British high commissioner in Kuala Lumpur acknowledged that, through the Malaysianization agreements, 'the change over to Malaysian management on estates has been smooth, orderly and unembittered [sic]'. Fenner was given a funeral with full police honours. As the high commissioner reflected:

There can be few ex-Colonies where the praise for an ex-Colonial Service officer has been so generously and publicly given [...] there is appreciation for the smooth way in which we organised the transfer of powerespecially when compared with neighbours like Indonesia. ${ }^{36}$

Where failings were revealed in indigenization, policymakers in Kuala Lumpur were not averse to rectifying these by continuing to call on British expertise. After 1960, with political support from the highest level, and the wresting of government accounts from the UK exchange banks, Malayan Banking Ltd (Maybank) emerged as the Federation's largest local bank (White 2004:78). But Maybank ran into liquidity difficulties in the course of 1965-1966 due to unwise lending. Bank Negara provided financial assistance and by 1971 owned $49 \%$ of Maybank's shares. Moreover, an expatriate general manager was seconded from National \& Grindlays, the British exchange bank, and Bank Negara was prepared to permit Grindlays a 15\% shareholding in Maybank. ${ }^{37}$

A smooth transition from the colonial to the national, and ongoing 'collaboration' (rather than Indonesian-style 'confrontation'), between former impe-

\footnotetext{
35 H\&C (Malaysia) to London, 14-8-1968, enclosing record of meeting at Ministry of Home Affairs, 6-3-1968, 37599, H\&c.

36 Hawley to Secretary of State, 23-6-1978, FCO 15/2356, TNA.

37 Extract from brief for visit to Malaysia, May 1971, OV 44/244, BoE.
} 
rial power and post-colonial elites, is illustrated by the final British military rundown in Singapore. Loh K.S. (2011:188) argues that the 'departing British themselves contributed significantly' to the growth of manufacturing, transport, and tourism in the hand-over of facilities. Three-quarters of the funding was tied to British goods and services (Loh K.S. 2011:189-90; White 2004:114), but the converted bases permitted the development of Singaporean industries during the 1970s-a commercial shipyard, an international airport, an engineering facility for electrical equipment, and tourist and recreational resorts. Moreover, the transition programme facilitated new educational provision: the relocation of the University of Singapore campus and a new technical college. In this, Singapore was glad to be able to utilize the expertise of the ex-colonials-in the transformation of the naval base into a commercial shipyard, British shipbuilders provided the know-how (Loh K.S. 2011:192, 194).

Indeed, throughout the transfer process, Lee Kuan Yew's regime remained alert to maintaining foreign-investor confidence (Loh K.S. 2011:189). Protests from British firms had accompanied the announcement of an accelerated military withdrawal (White 2004:108-11). Hence, in tandem with the rundown, both an investment guarantee for British companies and employment legislation to introduce a new labour discipline were announced. Retrained base workers acted as 'the vanguard of an adaptable national workforce spearheading the island's venture into manufacturing in the 1970s' (Loh K.S. 2011:195). As Loh concludes:

the accelerated British withdrawal was not only the final chapter of decolonisation in Singapore, but also the first step in the independent city state's growth. [...] The programmes of national development and social engineering, enabled by Anglo-Singaporean collaboration during the withdrawal, spurred the transformation of the island state into an international industrial hub (Loh K.S. 2011:200-1).

\section{Consequences for Economic Performance}

In contrast, most historians agree that Indonesia's sudden confrontational rupture with the Netherlands had negative consequences through the dislocation of supply chains and the exposure of chronic skills and capital deficits (Booth 1998:316, 2007:173; Lindblad 2010:105; Van Zanden and Marks 2012:149). The archipelago's poor economic performance vis-à-vis the peninsula was noted contemporaneously. Malaya's deputy prime minister, Tun Abdul Razak, told President Kennedy in April 1963 that the Indonesians were seriously con- 
cerned about the contrast between the record of prosperity and success which Malaya had achieved since independence and the series of mistakes and difficulties which had beset Indonesia. ${ }^{38}$

Marks and Van Zanden explicitly link Indonesia's woes to its 'troublesome economic decolonization', especially through their case studies of inter-insular shipping. The expulsion of the Koninklijke Paketvaart Maatschappij (K PM, Royal Packet Company) from Indonesian waters after 1958 resulted in a marked decline in productivity. Its successor Pelayaran Nasional Indonesia (PELNI, Indonesian National Shipping), which attempted to fill the gap left by КРм, lacked organizational skills and know-how. By 1960 PELNI was half as productive as KPM in the 1950s. Inefficiencies in infrastructure had knock-on effects: 'fragmented markets' [...] 'harmed economic growth' as economies of scale and specialization patterns between Java and the Outer Islands disintegrated. The absence of an 'integrated market', as long established networks between trading and shipping companies were disrupted, led to 'extreme temporal price fluctuations' (Marks 2010:81-2, 91; Van Zanden and Marks 2012:162, 164). ${ }^{39}$

This analysis is supported by the experiences of British trading and shipping interests. Being British-owned, Maclaine, Watson \& Co (MW), Blue Funnel's agents in Jakarta, dodged the first round of sequestrations (though the merchant house fell prey to the wave of anti-British takeovers in 1964). MW reported in late 1960 on PELNI's 'staggering' losses of Rp. 734 million. ${ }^{40}$ This was not a problem of supply. Gaps arising from the release of $40 \mathrm{KPM}$ vessels seized by the Indonesian government were quickly filled. Whereas PELNI had 38 ships in 1957, it possessed 91 by March 1960 (À Campo 1998:26, 34-5). Rather, the head of Djakarta Lloyd (DL), Indonesia's government-owned ocean-going shipping line, 'bemoaned' PELNI's 'lack of trained personnel.' ${ }^{41}$

PELNI's operations were hindered also by port congestion and delivery delays due to the inefficiencies of the bhakti, the nine state-owned trading houses which succeeded the Dutch import-export firms, winning monopoly rights to three-quarters of Indonesia's imports in April 1959 (Van Zanden and Marks 2012:149). MW reported to Liverpool in February 1960 that 'all was not well with the State enterprises' - a sad manifestation of which was the failure

38 Foreign Relations of the United States, 1961-1963, XXIII, Doc. 331. Memorandum of Conversation, Washington, 24-4-1963, available at: https://history.state.gov/historicaldocuments/ frus1961-63v23/d331, accessed 22-11-2016.

39 Disruptions in transport between Java and Sumatra also led to an acute labour shortage on the Deli plantation belt, a crucial earner of foreign exchange (Stoler 1985:149).

40 'Djakarta: Oct. 6o-Feb. 61', Spreckley to Holt, 19-12-196o, OA/1869/1.

41 Discussion between Holt and Kosasih, 26-3-196o, oA/1869. 
to supply textile orders in time for Lebaran (the Indonesian term for the Eid festival, when new clothes and footwear are traditionally purchased by celebrants and the bazaars are usually full of shoppers). ${ }^{42}$ On a visit to Indonesia in 1961, Holt reported it was 'not unknown' on quaysides to observe 'a once valuable piece of machinery or equipment with its wooden case literally decomposing about it.'43 In Surabaya and Semarang, a ministerial inspection party discovered in the summer of 1962 that machinery, textiles, and construction materials had been lying idle in warehouses for two years. ${ }^{44}$ Such blockages pushed up costs. Because ships frequently left port with unfilled space, freight rates had to be increased. PELNI bumped rates by $100-200 \%$ between 1957 and 1961 alone. ${ }^{45}$

Economic difficulties grew also out of the Indonesianization of deep-sea shipping through the exclusion of Dutch liners by 1960. New freight conferences were established, led by Britain's OSSCo and Indonesia's DL. By 1963, the latter was taking about $20 \%$ of the cargo from Europe and $15 \%$ on return voyages ${ }^{46} \mathrm{DL}$ faced a steep learning curve in transforming from a tramp organization, chartering vessels, to owning and running scheduled liners as a general carrier. Break-bulk shipping was a sophisticated art form, relying upon an interlocking network of agents, brokers, forwarders, insurers, exchange banks, and shippers, as well as shipping companies, maintained by relationships of trust over vast distances (Miller 2012:146-75). With the Dutch merchant firms out of the picture, D L utilized the services of the Indonesian state's freight forwarding organization (Badan Muatan Indonesia [BMI]). BмI's managers were inexperienced but also tended to discriminate against foreign shipping interests in giving DL first call on cargoes, a situation which the UK's Ministry of Transport representative in Singapore believed 'would only land Indonesia in extra costs and handicap her trade.47

DL's early dabbling in the Indonesia-Europe trade was not a success. Norman Etherington, the UN's shipping adviser to Indonesia, informed an OSSCo representative in January 1962 about 'his Minister's concern over the poor results which DL are achieving', and 'the lack of co-ordination amongst their

\footnotetext{
42 'Maclaines, London', Vinke to Holt, 15-2-196o, oA/1869/1.

43 Parcel 79, memorandum on harbours, c. Sept 1961, OA/1869/1.

44 '1962. Private Djakarta, April to July', Spreckley to Holt, 4-7-1962, enclosing extract from Business News 777/778, oA/1869/1.

45 '1961 Djakarta, June-Dec', copy of Day, chairman Indonesia-Europe Freight Conference, to Ismojo, DL, 29-11-1961, OA/1869/1.

46 'Ministry of Transport correspondence', Hobhouse to Gardner, 31-5-1963, OA/1869/2.

47 Beagley to Dickinson, 25-7-1960, MT 59/3234, TNA.
} 
Agents. ${ }^{48}$ But DL's executives were hidebound by the overbearing influence of the ministry on its operations. In 1960, Holt was told by Kosasih, head of DL, that the latter 'did not approve' of plans to purchase Polish- and Japanese-built vessels, wishing to see a more phased expansion of D L with British-owned tonnage filling the gap. Kosasih was also battling against naval 'interference.'49 In 1962 DL suspended its Indonesia-Japan service, despite its good prospects, given that one vessel had been sequestered by the navy, and two others seconded to PELNI. ${ }^{50}$ Ideological inflexibility, meanwhile, stymied Etherington's plan to overcome Indonesia's shipping problems by employing a European contractor because 'the Government preferred to restrict the influence of foreigners to what it now is.'51

Dutch interests experienced a reprise with the settling of the Irian Jaya dispute and the emergence of Britain as Indonesian enemy number one in the 'Ganyang Malaysia' (Crush Malaysia) campaign. In February 1965, copra, tea, and timber shipments recommenced to the Netherlands. ${ }^{52}$ Consignments were offered again to Dutch ships, including the Nsmo (despite its British ownership). From the autumn of 1965 , with a f10o million credit guarantee offered by the government in The Hague, some Dutch capital, services, and personnel returned. But this was on a contract basis only for the state-owned successors to the Dutch - for example, in the rehabilitation of tin dredges, and sugar and palm-oil factories. ${ }^{53}$ There would be no return of direct investment from the Netherlands. Even limited Dutch re-engagement was feared in Jakarta as a 'Trojan Horse. ${ }^{54}$

Indonesia's economic implosion continued. In March 1965, Tanjung Priok, Jakarta's port, was closed to foreign shipping because the congestion had made it 'virtually unworkable.55 The situation was no better in Sumatra. The backlog

48 '1962 Jan-March. Djakarta', Caldicott, Singapore to Holt, 20-1-1962, OA/1869/1.

49 Discussion with Holt, 26-3-196o, oA/1869.

5o '1962 Jan-March. Djakarta', extract from letter to Butterfield \& Swire, Tokyo in Graham, MW, Jakarta to Holt, 27-3-1962, OA/1869/1.

51 'Djakarta 1963', Graham to Holt, 11-1-1963, OA/1869/1.

52 'Djakarta.Jan-Mar 1965', NSMO, Amsterdam to NSMO, Jakarta and NSMO, Jakarta to NSMO, Amsterdam, 5-2-1965, OA/1869/2.

53 'Current Djakarta correspondence', Boerstra, NSMO, Jakarta to Holt, 8-9-1965, enclosing extract from Antara, 1-9-1965, OA/1869/2; Boerstra to Amsterdam, 13-10-1965, enclosing extract from Antara, 23-9-1965.

54 Gleichman, NSmo to Holt, 17-11-1964, reporting conversation with Ismojo, head of DL, oA/1696/2.

55 'Djakarta. Jan-Mar 1965', Holt to Gleichman, 15-3-1965, OA/1869/2. 
of exports was such that passenger services on the Deli railway were suspended so that the locomotives could pull the freight trains. But only one-third of the engines were in working order, spare parts being unobtainable given the shortage of foreign exchange. ${ }^{56}$ In July, 'bad port conditions and lack of shipping' meant that 100,000 chests of tea were stored on the estates awaiting shipment. ${ }^{57}$ The gridlock proved difficult to alleviate under the New Order. Blue Funnel's British-listed liners returned to Indonesian ports after 1967, but 'ship delays and cargo uncertainty persist[ed]. ${ }^{58}$

Their more gradual economic decolonization meant that Malaysia and Singapore did not suffer the same dislocations. British ship-owners were not enamoured with Port Swettenham (renamed Klang after 1972). What was being promoted as the peninsula's principal entrepot was described in November 1963 by the OSSCo's agents as a 'mess'. New wharves were expected to provide only a 'partial improvement'.59 But Sir Paul Chambers, the chairman of Imperial Chemical Industries, one of the UK's leading exporters, 'spoke enthusiastically' in November 1965 about 'the cargo handling methods on Singapore's new berths' ${ }^{60}$ Though after 1965 Malaysia's long-term objective was to reduce dependence upon Singapore, liberal exchange controls meant that exporters in southern Malaya could still use the island's import-export facilities. The dredging required at Klang would not allow Malaysia to receive container ships until 1973 (a year after Singapore), but Ocean managers were confident that shippers could forward goods by rail to Singapore in the interim. ${ }^{61}$

They could also use the feeder services of the British-controlled and Singapore-registered Straits Steamship Company (SSCo), which was the equivalent of KPM/PELNI in Malaysia's and Singapore's local shipping service, and was part of the Liverpool-based Ocean group. The post-colonial experiences of KPM and SSCo proved very different. The former diversified into trades outside Indonesia in other parts of Asia, southern Africa and South America, even before the takeover of December 1957 (À Campo 1998:14, 28-9). The latter continued to contribute to the modernization of Malaysia and Singapore for two and a half decades after the independence of Malaya.

\footnotetext{
56 Visit to Medan, 13/14-2-1965 by Boerstra, 19-2-1965, OA/1869/2.

57 'Current Djakarta correspondence', Boerstra to Amsterdam, 13-7-1965, OA/1869/2.

$5^{8}$ OSSCo Annual Report and Accounts (hereafter AR\&A/Cs) 1968:15-18, OA/4031/1.

59 McNeill, Mansfields to McDavid, Glen Line, 29-11-1963, OA/2116.

6o Reported from Minister of Transport's Advisory Panel meeting by Sir John Nicholson, chairman OSSCo, 'Shipping Advisory Panel, 1963', letter to Wingate, Mansfields, 2-12-1965, OA/1870.

61 Blue Funnel Line (BFL) minutes, 20-7-1970, OA/1772/4.
} 
There were tougher operating conditions by the early 1970s. The Malaysian International Shipping Corporation (MISC) and Singapore's Neptune Orient Line (NOL), aided by flag discrimination and/or priority berthing arrangements, encroached on SSCo activities. Political pressures led to the holding down of freight rates and the switch of port charges from consignees to shipowners. ${ }^{62}$ Yet, SSCo co-existed with the national lines. Though providing a useful instrument for the suppression of regional rebellions through troopcarrying, KPM rejected indigenization or any further cooperation with the Indonesian government during the 1950s, thus 'accelerat[ing] the decolonization crisis' (À Campo 1998:36). In 1960, however, SSCo formed a Malayan subsidiary, known as Kris. This succeeded to SSCo's shipyard at Butterworth, and ran its own fleet, flying the Federation's ensign, in the trades between Penang and the Malayan coast ports, Thailand, Burma, and Indonesia. Malayan directors were appointed to the board, and indigenes were trained as officers. Nevertheless, day-to-day management remained in the hands of Mansfields, the managers of SSCo who also happened to be the Liverpool parent's wholly owned Singapore-based shipping agents. ${ }^{63}$

To preserve its intra-Malaysian shipping, bumiputera capital was increasingly brought into Kris. Services out of Klang were controlled by the Malay majority by 1978 . Management was also indigenized. ${ }^{64}$ By 1975 , over 50 of SSCo's 65 executive staff in Singapore and Malaysia were permanent residents. ${ }^{65}$ SSCo's future was secured in a consolidation of the Ocean group's Southeast Asian interests in 1973. SSCo merged with Mansfields (as well as Blue Funnel's Straits-West Australia service), retaining both its British control and its role in shipping. But SSCo also diversified into related, cutting-edge activities. Centred on the Singapore hub, the SSCo group developed integrated land, sea, and air services, with intermodal distribution networks made possible by the new methods of containerization and computerization. By the mid 1970s, as well as shipping, SSCo's portfolio covered precision engineering, offshore oil-industry services, air transportation and freight-forwarding, travel and tour operation, car rental, data processing, and property development and management. ${ }^{66}$

62 Notes by Alexander, chairman OSSCo for directors, 1-5-1970 and 12-2-1971, OA/JLA/22/3.

63 'Shipping company formed with \$30 million capital', Malay Mail, 5-12-196o.

64 Ocean Transport \& Trading (отT) Ltd board minutes, 23-7-1974 and 28-1-1975, OA/JLA/27/1; otT Ltd AR\&A/Cs 1977, OA/5001/7; OTT Ltd AR\&A/Cs 1978, OA/5001/8.

65 Ocean: The Journal of the Ocean Steam Ship Company 1975:131, OA/697/2.

66 Ocean: The Journal of the Ocean Steam Ship Company December 1971:5-7; 1975:128-31, $\mathrm{OA} / 697 / 2$. 
In 1979, SSCo experienced its highest pre-tax profits ever recorded. ${ }^{67}$ In 1983, Ocean disposed of its $58 \%$ shareholding in SSCo, given the limited cash dividends and an over-supply of property on the Singaporean market. ${ }^{68}$ This, however, was a voluntary divestment by the multinational logistics group. It was not forced by the host governments, and did not result in the organizational skills gap that was experienced in Indonesia.

There would be no 'crowding out' of foreign capital in ocean-going shipping either. Blue Funnel's sailings eastward were reduced from eight to seven sailings per month in 1971, given competition from MISC and NOL. ${ }^{69}$ By 1978 , Singapore possessed Asia's second-largest fleet; by 1981, NOL was the world's twelfth-largest container-shipping company (Broeze 1987:85, 2002:65). With easy access to credit as a government-linked corporation, MISC grew rapidly, too (Broeze 1987:88).

But Blue Funnel Line managers were confident back in 1972 that Singapore's government was 'dedicated to increased trade' and was unlikely therefore to 'restrict cargo to Gov[ernmen]t loaders'. MISC might 'fiddle' the rules, but it was not expected to leave the British-dominated Far East Freight Conference (FEFC), as Kuala Lumpur had openly announced support for the conference. ${ }^{70}$ In the 1980s, MISC still carried 'but a small share of Malaysia's overseas trade' (Broeze 1987:88). Singapore's outward-facing economic development strategy was confirmed in the containerization of its port from the late 196os onwards (Levinson 2006:210-11). Malaysia followed suit, and, by the 1970s, viewed transport modernization as a new realm of activity for bumiputera capital and management, but not to the exclusion of overseas shipping interests. ${ }^{71}$ Indonesia was not containerized until $1981 .{ }^{72}$ Tanjung Priok did not feature among the world's top 20 container ports in the 1980 s and 1990s, whereas Singapore was a stalwart (and the leader in 1991) of this list, and Klang arrived on it in 1999 (Broeze 2002:169, 202).

\footnotetext{
67 otT Ltd AR\&A/Cs 1979:5, OA/5001/9.

68 otT Ltd AR\&A/Cs 1983:3, OA/5001/13.

69 BFL minutes, 3-5-1971, OA/1772/5.

70 BFL minutes, 28-4-1972, OA/1773.

71 Material in $\mathrm{H} \& \mathrm{C}, 37600$.

72 otT Ltd AR\&ACs 1981:4, OA/5001/11.
} 


\section{Conclusion: Neo-Colonialism Redux?}

Given Malaysia's and Singapore's open attitudes to foreign capital it might be tempting to conclude that British decolonization produced quisling satellite states. But this was an increasingly anachronistic trope, as plantation and mining companies were Malayized in the 1970 s and 1980s, and from the late $1950 \mathrm{~s}$ land improvement, replanting, and price stabilization schemes in Malaya/ Malaysia favoured indigenous smallholders rather than big plantations (Henley 2012: S33-4; Ong 2015:96, 98, 121-2).

Nor was Anglophone Southeast Asia constricted by British financial interests. Even in his revival of neo-Marxist interpretations of decolonization, Sutton recognizes that Malayan ministers were able to win concessions between 1956 and 1957, notably post-colonial military and development aid, given Britain's dependency upon Malaya's dollar earnings (Sutton 2015:152-9). Sticking with sterling into the early 1970 s on the part of both Malaysia and Singapore was not the jejune reluctance of a fledgling to leave the nest, but rather was caused by the appreciation of Malaysian decision-makers that there was little alternative, given the weakness of the us dollar (which was devalued in December 1971 and again in February 1973). Tokyo, on the other hand, had still not made available effective facilities for the yen to be held by non-residents, while interest rate differentials ensured that sterling assets yielded a higher return than those valued in dollars. ${ }^{73}$

In contrast to Indonesia's sudden rupture with the Netherlands, Malaysia and Singapore chose incremental ways of 'breaking free', and proved themselves adept at bending foreign investment to meet national objectives. Moreover, during the 1960s, Malaysia and Singapore were capable of subverting the designs of long-established British business interests, when that suited them. The emergence of MISC and NOL, for example, represented the rejection of a plan put up in 1962 by the British ship-owners to form their own Malayan subsidiary within FEFC. The UK lines thus ended up with their nightmare scenario conjured up at the Singapore split: 'two Lines extra instead of only one. ${ }^{74}$

In further critique of neo-colonialist models, local elites had considerable agency in the decolonization process (Stockwell 1998; Thomas, Moore and Butler 2015:343), even 'if some were used as European instruments to "organize" independence in ways conducive to European interests' (Dülffer and Frey

\footnotetext{
73 Note for the record, 11-3-1971, ov 44/244, BoE; Note of a meeting, 14-5-1971; Meeting with Malaysian Treasury and Bank Negara officials, 12-4-1972, ov 44/245; Note by Fogarty for Acting High Commissioner, 29-1-1971 in Fogarty to Marshall, 29-1-1971.

Thomson, Ben Line to Nicholson, 18-8-1965, OA/2116.
} 
2011:2-3). The configuration of indigenous powerbrokers varied from territory to territory, and this diversity influenced how decolonization compacts were subsequently rejected, accepted, or adapted in post-colonial states.

Malaysia's ruling political class was an amalgam of Malay aristocrats-turnedadministrators and Chinese and Indian business leaders. They were unlikely to seek an overnight overhaul of economic relations with the former imperial power. The first two ministers of finance in Kuala Lumpur, H.S. Lee (1956-1959) and Tan Siew Sin (1959-1974), were wealthy towkay (business and community leaders) whose tin, rubber, and trading interests relied upon global markets. The case of Singapore, despite the shared British colonial heritage, was not identical. The left-leaning professionals who came to dominate the PAP were distanced from Singapore's Chinese business elite, and more inclined toward state intervention in the economy. Despite being a cousin of Tan Siew Sin, Goh Keng Swee, Singapore's first finance minister (1959-1967), began his career as a civil servant in the post-war Department of Social Welfare. This likely explains why Singapore was more prepared to challenge the sterling-area compact in the late 1960 s/early $1970 .^{75} \mathrm{NOL}$, revealingly, was completely government-owned, whereas M ISC had a $40 \%$ shareholding from the private sector, and was headed by the well-connected entrepreneur Robert Kuok. ${ }^{76}$

Even so, Singapore's state-led capitalism did not entail an Indonesian-style rejection of foreign private enterprise. Lacking the protection of a Greater Malaysian common market after the 1965 divorce, as well as a primary producing export base, the island state sought export-oriented industrialization (EOI) to provide employment opportunities to tame the PAP's power base in the 'politically powerful labor class'. To remain globally competitive, Singapore's economic development required foreign capital (Ritchie 2009:439).

After touring Republican-held areas of Indonesia in early 1947, George Holt shrewdly appreciated that ' $[\mathrm{m}]$ ost Holland-educated Indonesians naturally gravitated to left-wing circles in Europe and the view commonly held by the left-wing in Holland that the Netherlands Indies was being exploited by Dutch and other European capitalists, has [...] become orthodox opinion.' ${ }^{77}$ Increasingly under the spell of the PKI, hostility towards expatriate enterprises was central to Sukarno's philosophy. The MCP made a comeback in the 1960 and

75 In the restructuring of the sterling area after the devaluation of 1967 , Singapore was branded by the Bank of England as a 'difficult customer' prone to look 'exclusively at her own narrow interests', with, inter alia, ambitions to develop an international money market to rival colonial Hong Kong's. Note by Stone, 21-3-1972, ov 44/195.

76 BFL minutes, 28-4-1972, OA/1773.

77 Holt to Hobhouse, 17-3-1947, enclosing report on visit, 21 Feb-8 March, OA/2537/1. 
1970s, but yet again in the guise of armed struggle, and the Malaysian communists never played the power-broking role of their Indonesian comrades (Ong

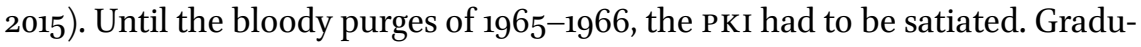
alism was less of an option in Indonesia, and anti-Westernism proved difficult to shake off in the 1970 .

Yet, in the cases of Malaysia and Singapore, development strategies were less reactive against the ex-colonial presence, and so less retarding for the postcolonial economies, because the decolonization settlements in Anglophone Southeast Asia were so much less restrictive. Tipton identifies a rejection of colonialism as a key ingredient in the forging of Southeast Asia's state-led capitalisms. But the 'existential envy or ressentiment' was always of an angrier order in Indonesia compared to Malaysia and Singapore (Tipton 2009:420). In 1961, Indonesia's shipping adviser, Norman Etherington, opined that 'Britain had gained a great reputation in granting to her former colonies political and economic independence' in contrast to 'the Belgians and the Dutch who had tried to get away with conceding only the former. ${ }^{78}$

\section{References}

\section{Archives}

BoE Bank of England

H\&C London Metropolitan Archive, Harrisons \& Crosfield Ltd Archive, London

OA Merseyside Maritime Museum, Liverpool, Ocean Archives

TNA The National Archives of the United Kingdom

\section{Published Sources}

À Campo, J.N.F.M. (1998). 'Business not as usual: Dutch shipping in Indonesia, 19451958', International Journal of Maritime History 10-2:1-39.

Amoroso, Donna J. (2014). Traditionalism and the ascendancy of the Malay ruling class in colonial Malaya. Singapore: NUS Press.

Booth, Anne E. (1998). The Indonesian economy in the nineteenth and twentieth centuries: A history of missed opportunities. Basingstoke: Macmillan.

Booth, Anne E. (2007). Colonial legacies: Economic and social development in East and Southeast Asia. Honolulu: University of Hawai'i Press.

Boyce, D. George (1999). Decolonisation and the British Empire, 1775-1997. Houndmills/ Basingstoke/Hampshire: Macmillan.

78 '1961 Djakarta, June-Dec', conversation reported in Spreckley to Holt, 10-7-1961, OA/1869/1. 
Broeze, Frank (1987). 'From imperialism to independence: The decline and re-emergence of Asian shipping', The Great Circle 9-2:73-95.

Broeze, Frank (2002). The globalisation of the oceans: Containerisation from the $1950 \mathrm{~s}$ to the present. St. John's, Newfoundland: International Maritime Economic History Association.

Cmnd. 9714 (1956). Self-government for the Federation of Malaya: Report of the Constitutional Conference, London, January-February 1956. London: HMso.

Cribb, Robert (2000). Historical atlas of Indonesia. Richmond, Surrey: Curzon.

Dick, Howard (2002). 'Formation of the nation-state, 1930s-1966', in: Howard Dick, Vincent J.H. Houben, J. Thomas Lindblad and Thee Kian Wie (eds), The emergence of a national economy: An economic history of Indonesia, 180o-20oo, pp. 153-93. Crows Nest, Nsw: Allen \& Unwin.

Düllfer, Jost and Marc Frey (2011). 'Introduction', in: Jost Dülffer and Marc Frey (eds), Elites and decolonization in the twentieth century, pp. 1-10. Houndmills: Palgrave Macmillan.

Eng, Pierre van der (1998) 'Marshall Aid as a catalyst in the decolonization of Indonesia, 1947-9', Journal of South East Asian Studies 19-2:335-52.

Frankema, Ewout (2015). 'The green revolution in Indonesia: A replicable success?', in: Alicia Schrikker and Jeroen Touwen (eds), Promises and predicaments: Trade and entrepreneurship in colonial and independent Indonesia in the $19^{\text {th }}$ and $20^{\text {th }}$ centuries, pp. 259-78. Singapore: Nus Press.

Groves, H.E. (1978). 'Fundamental liberties in the constitution of the Federation of Malaysia', in: Tun Mohamed Suffian, H.P. Lee and F.A. Trinidade (eds), The constitution of Malaysia: Its development: 1957-77. Kuala Lumpur: Oxford University Press.

Gullick, J.M. (1992). Rulers and residents: Influence and power in the Malay states, 18701920. Singapore: Oxford University Press.

Harper, T.N. (1999). The end of Empire and the making of Malaya. Cambridge: Cambridge University Press.

Henley, David (2012). 'The agrarian roots of industrial growth: Rural development in South-East Asia and sub-Saharan Africa', Development Policy Review 3o-S1: S25-S47.

Henley, David, Riwanto Tirtosudarmo, and Ahmad Helmy Fuady (2012). 'Flawed vision: Nigerian development policy in the Indonesian mirror, 1965-90', Development Policy Review 30-s1: S49-S71.

Hill, Hal (1998). Foreign investment and industrialization in Indonesia. Singapore: Oxford University Press.

Holland, R.F. (1985). European decolonization, 1918-1981: An introductory survey. Houndmills: Macmillan.

Hopkins, A.G. (2008). 'Rethinking decolonization', Past and Present 200-1:211-47.

Huff, W.G. (1994). The economic growth of Singapore: Trade and development in the twentieth century. Cambridge: Cambridge University Press. 
Hutchinson, Francis E. (2015). 'Malaysia's independence leaders and the legacies of state formation under British rule', Journal of the Royal Asiatic Society 25-1:12351.

Jeffery, Keith (2011). 'Round table on Imperial endgame by Benjamin Grob-Fitzgibbon', Britain and the World 4-2:325-28.

Jomo, K.S. and Wee Chong Hui (2014). Malaysia@5o: Economic development, distribution, disparities. Singapore: World Scientific.

Jones, Matthew (2002). Conflict and confrontation in South East Asia, 1961-1965: Britain, the United States, Indonesia and the creation of Malaysia. Cambridge: Cambridge University Press.

Knight, Roger (2015). Trade and Empire in early nineteenth century Southeast Asia: Gillian Maclaine and his business network. Woodbridge, Suffolk: Boydell.

Lange, Matthew (2009). Lineages of despotism and development: British colonialism and state power. Chicago: University of Chicago Press.

Lange, Matthew, James Mahone and Matthias vom Hau (2006). 'Colonialism \& development: A comparative analysis of Spanish and British colonies', American Journal of Sociology 111-5:1412-62.

Lee Kuan Yew (2000). From Third World to First: The Singapore story, 1965-200o. New York: HarperCollins.

Levinson, Marc (2006). The box: How the shipping container made the world smaller and the world economy bigger. Princeton: Princeton University Press

Lindblad, J. Thomas (2008). Bridges to new business: The economic decolonization of Indonesia. Leiden: KITLV Press.

Lindblad, J. Thomas (2010). 'Economic growth and decolonisation in Indonesia', Itinerario 34-1:97-112.

Loh Kah Seng (2011). 'The British military withdrawal from Singapore and the anatomy of a catalyst', in: Derek Heng and Syed Khairudin Aljunied (eds), Singapore in global history, pp. 185-204. Amsterdam: Amsterdam University Press.

Loh Wei Leng (2002). 'The colonial state and business: The policy environment in the inter-war years', Journal of Southeast Asian Studies 33-2:243-56.

Marks, Daan (2010). 'Lost decades? Economic disintegration in Indonesia's early independence period', Itinerario 34-1:77-96.

Means, Gordon P. (1976). Malaysian politics. 2nd ed. London: Hodder \& Stoughton.

Means, Gordon P. (1991). Malaysian politics: The second generation. Singapore: Oxford University Press.

Miller, Michael B. (2012). Europe and the maritime world: A twentieth century history. Cambridge: Cambridge University Press.

Mohamed Suffian bin Hashim, Tun (1976). An introduction to the constitution of Malaysia. 2nd ed. Kuala Lumpur: Oxford University Press.

Moore, Bob (2015). 'An "ethical imperialism"? The Dutch colonial empire before 1945', 
in: Martin Thomas, Bob Moore and L.J. Butler (eds), Crises of Empire: Decolonization and Europe's imperial states, pp. 229-43. 2nd ed. London: Bloomsbury.

Ong Weichong (2015). Malaysia's defeat of armed communism: The Second Emergency, 1968-1989, Abingdon: Routledge.

Pelzer, Karl J. (1982). Planters against peasants: The agrarian struggle in East Sumatra. 's-Gravenhage: Martinus Nijhoff.

Penders, C.L.M. (2002). The West New Guinea debacle: Dutch decolonisation and Indonesia, 1945-1962. Adelaide: Crawford House.

Ricklefs, M.C. (1993). A history of modern Indonesia since c. 130o. 2nd ed. Houndmills: Macmillan.

Ritchie, Bryan K. (2009). 'Economic upgrading in a state-coordinated, liberal market economy', Asia Pacific Journal of Management 26-3:435-57

Round Table Conference (1950). 'Results as accepted in the Second Plenary Meeting held on 2 November 1949 in the "Ridderzaal" at The Hague'. Secretariat-General of the Round Table Conference [the published version of the agreement].

Schenk, Catherine R. (2008). 'Malaysia and the end of the Bretton Woods System, 196572: Disentangling from sterling', Journal of Imperial \& Commonwealth History 362:197-220.

Shakila Yacob and Nicholas J. White (2010). 'The "unfinished business" of Malaysia's decolonisation: The origins of the Guthrie "dawn raid", Modern Asian Studies 445:919-6o.

Sheridan, L.A. (1977). 'The mysterious case of the disappearing business: Government of Malaysia \& Another v. Selangor Pilot Association', Journal of Malaysian and Comparative Law 4-1: 5-17.

Smith, Simon C. (1995). British relations with the Malay rulers from decentralization to Malayan independence, 1930-57. Kuala Lumpur: Oxford University Press.

Stockwell, A.J. (1986). 'British imperial strategy and decolonization in South-East Asia, 1947-1957', in: D.K. Bassett and V.T. King (eds), Britain in South-East Asia, pp. 79-9o. Hull: Centre for South-East Asian Studies.

Stockwell, A.J. (1995a). 'Introduction', in: A.J. Stockwell (ed.), Malaya; Part I: The Malayan Union experiment, 1942-1948, pp. xxxi-lxxxiv. London: HMso.

Stockwell, A.J. (ed.) (1995b) Malaya; Part II: The Communist Insurrection, 1948-1953. London: HMso.

Stockwell, A.J. (ed.) (1995c) Malaya; Part III: The Alliance route to independence, 19531957. London: HMSO.

Stockwell, A.J. (1998). 'Malaysia: The making of a neo-colony?', Journal of Imperial \& Commonwealth History 26-2:138-56.

Stockwell, A.J. (2004a). 'Introduction', in: A.J. Stockwell (ed.), Malaysia, pp. xxxv-xcv. London: TSO.

Stockwell, A.J. (ed.) (2004b). Malaysia. London: Tso. 
Stoler, Ann Laura (1985). Capitalism and confrontation in Sumatra's plantation belt, $1870-$ 1979. 2nd ed. Ann Arbor: Michigan University Press.

Subritzky, John (2000). 'Britain, Konfrontasi, and the end of Empire in Southeast Asia, 1961-5', Journal of Imperial \& Commonwealth History 28-3:209-27.

Sutton, Alex (2015). The political economy of imperial relations: Britain, the sterling area, and Malaya, 1945-196o. Houndmills: Palgrave Macmillan.

Thee Kian Wee (1996). 'Economic policies in Indonesia during the period 1950-65', in: J. Thomas Lindblad (ed.), Historical foundations of a national economy in Indonesia, 189os-199os. Amsterdam: Royal Netherlands Academy of Arts and Sciences.

Thee Kian Wee (2003). 'Introduction', in: Thee Kian Wee (ed.), Recollections: The Indonesian economy, 1950s-199os, pp. 3-43. Singapore: ISEAS.

Thee Kian Wee (2010). 'The debate on economic policy in newly-independent Indonesia between Sjafruddin Prawiranegara and Sumitro Djojohadikusumo', Itinerario 34-1:35-56.

Thee Kian Wee (2015). 'The Indonesian economy during the 1950s and early 1960s and America's proposal for economic aid', in: Alicia Schrikker and Jeroen Touwen (eds), Promises and predicaments: Trade and entrepreneurship in colonial and independent Indonesia in the $19^{\text {th }}$ and $20^{\text {th }}$ centuries, pp. 198-212. Singapore: NUS Press.

Thomas, Martin, Bob Moore, and L.J. Butler (2015). Crises of Empire:Decolonization and Europe's imperial states. 2nd ed. London: Bloomsbury.

Tipton, Frank B. (2009). 'Southeast Asian capitalism: History, institutions, states and firms', Asia Pacific Journal of Management 26-3:401-34.

Trinidade, F.A. and H.P. Lee (1986). 'Suffian's contribution to Malaysian constitutional law', in: F.A. Trinidade and H.P. Lee (eds), The constitution of Malaysia: Further perspectives and developments. Singapore: Oxford University Press.

Weinstein, Franklin B. (1974). Indonesian foreign policy and the dilemma of independence: From Sukarno to Soeharto. Ithaca: Cornell University Press.

White, Nicholas J. (1996). Business, government, and the end of Empire: Malaya, 1942-57. Kuala Lumpur: Oxford University Press.

White, Nicholas J. (2004). British business in post-colonial Malaysia, 1957-7o: 'Neo-colonialism' or 'disengagement'? London and New York: Routledge.

White, Nicholas J. (2006). 'The state and economic development in twentieth-century Malaysia', in: Richard Mason and Abu Talib Ahmad (eds), Reflections on Southeast Asian history since 1945, pp. 77-93. Penang: Universiti Sains Malaysia Press.

White, Nicholas J. (2010). 'Malaya and the sterling area reconsidered: Continuity and change in the 1950s', in: Shigeru Akita and Nicholas J. White (eds), The international order of Asia in the 1930s and 1950s, pp. 151-78. Farnham, Surrey: Ashgate.

White, Nicholas J. (2011). 'Reconstructing Europe through rejuvenating Empire', Past \& Present-s-6:209-36.

White, Nicholas J. (2012). 'Surviving Sukarno: British business in post-colonial Indonesia, 1950-67', Modern Asian Studies 46-5:1277-1315. 
Wilson, Harold (1971). The Labour government, 1964-70: A personal record. London: Weidenfield \& Nicholson.

Zanden, Jan Luiten van and Daan Marks (2012). An economic history of Indonesia, 180o2010. Routledge: London and New York. 